\title{
Organization of career guidance for the specialization in Machinery and equipment for oil and gas fields
}

\author{
Rustem Suleimanov*, Marat Khabibullin, Minivaris Galimullin, Liliya Zaripova, and Lyaysan Zaynagalina \\ Ufa State Petroleum Technological University, Branch of the University in the City of Oktyabrsky, 54a, Devonskaya St., Oktyabrsky, \\ Republic of Bashkortostan, 452607, Russia
}

\begin{abstract}
The article reflects the activities aimed at shaping the views of applicants and students on the independent choice of profession. The authors analyze the work of the department in this area. The factors affecting the formation of graduate competencies are considered and attention is focused on improving these qualities. The tasks and goals of career guidance for the younger generation, and methods for achieving positive results are examined. On the basis of the above-mentioned, the main directions for the development of the competence of graduates are formulated and recommendations are made for improving these indicators.
\end{abstract}

\section{Introduction}

The future of any institution of higher education is largely determined by such activities, which are carried out as part of career guidance.

Technological universities are increasingly turning their attention to the level of pre-university education of potential applicants. This is due to the annual increase in the number of gifted and promising students. Preuniversity education orients students to new living conditions - the specifics of receiving higher education.

Modern society makes quite high demands on the level of professional training of specialists in the field of the oil industry. In this regard, certain problems associated with the choice of professional activity by schoolchildren are quite relevant. Today the career guidance for schoolchildren is not so much a pedagogical as a social issue. The essence of career guidance as a social issue is to destroy the contradiction between the obvious needs of schoolchildren in a balanced structure of the labor market and incorrectly formed expectations of young people when they are infused into the working environment.

This is a huge and large-scale work, the main goal of which is the creation of favorable conditions under which the applicant would apply for entry into the branch of the Federal State Budgetary Educational Institution of Higher Education Ufa State Petroleum Technological University (USPTU) in in the city of Oktyabrsky. Then he would proudly tell everyone that he made the right choice [1].

This is achieved by the joint work of the branch and educational institutions of general secondary and vocational education. On the part of the branch, the participants in such activities are academic teaching staff, departments, especially graduating departments, student activists, and branch administration. On the educational institutions' side, such participants are schools, gymnasiums, lyceums, colleges. An important role is assigned to working youth from the industrial enterprises of the city [2-4].

The tasks solved during career guidance are the following:

1. Creating a positive image of a branch in the city of Oktyabrsky, in the Republic of Bashkortostan, in the Russian Federation and abroad.

2. Organization of joint activities of the branch and educational institutions of the city and surrounding areas.

3. Collecting information about talented young people potentially targeting entry into university.

4. Implementation of regulatory indicators, reflecting the activities of the branch.

5. The study of the contingent of schoolchildren to calculate the expected number of applicants for several years in advance.

\section{Materials and methods}

Since 2011, the branch of the Federal State Budgetary Educational Institution of Higher Education Ufa State Petroleum Technological University in the city of Oktyabrsky has been training the students in Bachelor's degree programme 15.02.03 "Technological machines and equipment", specialization in "Machines and equipment for oil and gas wells". The first graduation of students took place in 2015. In order to achieve maximum results in the future career growth of a graduate, career guidance is carried out in various areas. The long-term experience of the graduating department

\footnotetext{
Corresponding author:
} 
"Oilfield Machinery and Equipment" has a great influence. For more than 45 years of the department's existence, more than 4,000 engineers have been trained for the oil and gas industry.

The current situation in the training of competent graduate is not only to teach students professional skills but also to address issues of their employment and career growth. Further professional development of a graduate is not determined at the time of obtaining a higher education diploma but at the time of choosing a field of training and specialization. This is influenced by the following factors: social, psychological, economic; but most applicants are guided by: 1) the prestige of the profession; 2) the opinion of parents or friends; 3 ) the cost of training, and to a small extent they consider the issues of self-realization in the workplace and the demand for training programme. And even if a student consciously strives for knowledge, this still does not guarantee the success in competition with graduates from other universities.

As part of the vocational training programme, the following tasks are performed during the implementation of career guidance:

- the formation of motivation to work and acquisition of profession among schoolchildren;

- the study of methods and ways of searching the information on professional activities, vocational education, personnel market, job vacancies, job service;

- informing schoolchildren about the prospects of vocational education and further professional activities;

- acquisition of work experience in the workplace, in accordance with the interests and abilities of students;

- the implementation of conditions for career guidance for schoolchildren, using the skills of academic teaching staff; cooperation of schools with specialized enterprises, educational institutions, career guidance centers; work with parents;

- informational support for schoolchildren about the differences between various areas of professional activity in the labor market;

- the use of different means to support schoolchildren in their choice of future professions, including the identification of professional inclinations and the real potential of schoolchildren to continue their education and choice of profession.

Today raising the competence of graduates is a pressing issue. On the one hand, the demands imposed by employers are increasing, on the other hand, the claims of graduates themselves are growing. The competence of a graduate is influenced by: 1) the quality of training in an educational institution; 2) practical industrial training, 3) availability of production experience; 4) formation of personal qualities [5].

The quality of graduate training is evaluated by the following criteria: 1) professional knowledge; 2) the desire for professional growth; 3) level of communicative culture; 4 ) the ability to reflection (i.e, to thinking, self-observation, self-knowledge) [6].

The quality of training is largely facilitated by: 1) the history of the university and the traditions that have developed over the years; 2) the quality of the material and technical base: 3 ) the quality of the scientific and methodological base; 4) the potential of the academic teaching staff.

A graduate must be confident in his abilities, this is facilitated by: 1) the mastering and improvement of professional skills; 2) adequate behavior in different situations; 3 ) maintaining and improving the health and working capacity; 4) the creation of a favorable appearance, own image.

The personal ambitions of a graduate can have a negative effect: 1) inadequate self-esteem in the chosen specialty; 2) unrealistic expectations at the beginning of a career path; 3) excessive personal requirements.

Graduates can be divided into the following groups: 1) the most successful students with business and personal qualities, having several offers from different employers $(10 \%$ of the total number of graduates); 2) students aimed at success in professional activities, having work experience and positive employment practices $(40 \%)$; 3 ) students who do not have the ability to develop their professional careers, who do not make efforts to find work, are not independent in finding employment $(30 \%)$; 4) unmotivated students with uncertain plans for professional growth (20\%) [7].

To improve the quality of employment, the following actions are necessary: 1) the formation and replenishment of databases of graduates and employers' vacancies; 2) selection of candidates among graduates for vacancies and the organization of personnel interviews; 3) advising students on employment issues and writing a resume; 4) holding meetings and presentations with enterprises of the oil and gas complex [8].

But in turn, the graduate himself must have the following qualities: 1) abilities (a combination of professional skills with personal qualities), namely: a) leadership ability, b) ability for continuous selfdevelopment; c) the ability for continuous professional growth; 2) clarity of goals; 3) hard work; 4) enthusiasm; 5) initiative (self-setting and solving problems); 6) dependability and reliability (ability to perform routine work); 7) creative attitude to work (search for new ideas and expansion of their field of application); 8 ) sociability (the ability to simply and clearly impose their thoughts, freely and convincingly submit their ideas); 9) ability to take risks; 10) independence; 11) the desire for high-quality work; 12) stress tolerance [9].

If the graduate evaluates himself competent, then it helps to overcome: 1) individual psychological barrier; 2) depression, pessimism; 3) uncertainties in the life perspective; and also: 1) regulates his livelihoods; 2) helps him out of the impasse [10].

Oilfield Machinery and Equipment department has established cooperation with the following oil enterprises of the Russian Federation: OAO Tomskneft VNK (Tomskneft East Oil Company PJSC, Strezhevoy), NPF Paker (Scientific and Production Firm "Paker" LLC, Oktyabrsky), OAO RN-Nyaganneftegaz (RNNyaganneftegaz PJSC, Nyagan), OOO UK Sheshmaoil (Sheshmaoil management company LLC, Almetyevsk), OAO AK OZNA (Joint Stock Company OZNA PJSC, Oktyabrsky), OAO Udmurtneft (Udmurtneft PJSC, Izhevsk). Presentations and interviews have been 
conducted with students for employment and work experience.

Students being educated for the specialty of Mechanics are constantly participating in presentations organized by leading oil companies: Rosneft, Shlyumberzhe, Gazpromneft, Bejker Hyuz, etc., as well as in annual distributions organized by the USPTU. Our region has a powerful oil base, so a student, and later a graduate, is focused on this field of activity. And for effective training of specialists, interrelation with production is necessary, namely: 1) the inclusion in the educational process of disciplines and types of studies that are of increased importance for the oil enterprise; 2) the implementation of the diploma and course designing, as well as research within laboratory work on topics proposed by the enterprise; 3) carrying out practical exercises in real production conditions; 4) organization of internships for academic teaching staff at enterprises; 5) participation of students in scientific and technical conferences together with university professors and specialists of the enterprise; 6) the advance distribution of students (future graduates) by enterprises for practical training in order to adapt to the working environment; 7) an invitation of the leading engineering, technical and scientific workers of enterprises for teaching the students.

The following indicators are important for the realization of graduate capabilities directly at the enterprise: 1) the amount of time for the graduate to adapt at the beginning of work at the enterprise; 2) the number of related specialties in which a graduate can work without a significant investment of time and effort to master them.

It is necessary to introduce in educational presses in the branch teaching the methods of competently building a professional career, independent search for a workplace.

During the career guidance, the following activities are being done:

1) Presentation of the branch, coverage of its activities through the media;

2) Meetings with applicants, informing and advising on the issues of entering the branch and the prospects of the chosen specialization and a field of training;

3) Identification of applicants wishing to study at the branch in various forms of training;

4) Creating the attractiveness of the branch and the required conditions for future applicants to receive a competitive education.

The branch and Oilfield Machinery and Equipment department have gained experience working with students. Schoolchildren participated in the annual scientific and technical conference of young scientists, graduate students and students [5]. The reports prepared by schoolchildren reflected the connection of technical progress with nature, man, and its promising development, which were published in the conference materials.

During the conference, the participants familiarized themselves with the branch, its activities and equipment; study tours were conducted, also presentations, laboratory facilities, visual aids, and full-scale samples were shown. The survey showed that most of these students wanted to study at the branch.

Career guidance for schoolchildren should begin with the 1st grade and be built as follows:

- 1-4 grades - diagnostics and determination of abilities and interests of schoolchildren;

- 5-7 grades - creation and implementation of programmes for the development of abilities and interests of schoolchildren;

- 8 grade - the formation of professional interest in the professions among the schoolchildren;

- 9 grade - analysis of the qualities and characteristics of schoolchildren to adapt to the chosen profession;

- 10 grade - intermediate assessment of professional self-determination of schoolchildren;

- 11 grade - diagnostics, analysis and corrective actions in the self-determination of schoolchildren for further professional activity.

Within the framework of career guidance events organized to maintain the image of higher education institutions, an integral part is the holding of workshops on various topics. Oilfield Machinery and Equipment department actively participates in such events, presenting workshops on the following topics: 1) Overhaul of wells (December 2015), 2) Modern methods of oil production (January 2017), Systems of maintenance and repair of oil field equipment (February 2017); 4) Why do machines fail? (September 2017).

Preparation for the workshop is focused on the circle of students, which consists of students of secondary educational institutions. Submission of information is carried out taking into account the outlook of school students. The task of the organizers of the workshop is to interest them, to convey to them the importance of information. This information reveals the current state of the oil industry, new trends in development, new technological solutions, which make it possible to more effectively use the main fleet of oilfield equipment.

A workshop for schoolchildren is an essential tool for orienting and directing the young generation in the complex world of professions.

A workshop is a form of organizing the training of the listener in the form of interactive communication, in which the following processes are carried out: 1) the transfer of experience gained by the lecturer in the course of professional activity, 2) step-by-step actions that will lead to the planned result.

Workshops allow you to create direct contact between the schoolchildren and representatives of higher education institution, which is important for the professional orientation of the schoolchild.

Thus, the schoolchildren expand their outlook and can assess their capabilities when choosing a direction in their professional activities, as well as what skills are needed for future employment.

The two types of workshops are applied:

1) training, during which the listener gains abilities, knowledge, skills after mastering the submitted information material in the form of a business game; 
2) a demonstration, which provides information on the current state of development of oilfield equipment, on professional growth opportunities, on the specifics of work in production; it is presented in the form of a public lecture.

Listeners of workshops create an atmosphere of creativity and engage in the process itself. The lecturer himself should not only share his knowledge, but he should also involve all listener in the workshop process, make them be active. As a result of this action, students will be able to show their abilities, relax, and be active towards more professional self-expression.

All information presented at the workshop contributes to creating a pleasant atmosphere, developing the imagination of listeners, raising the image of the professional activity.

The workshop is largely dependent on the professionalism of the lecturer, who, as a result, sets the starting point when developing the concept of this exciting organizational and educational activities.

Several workshops take place at the same time during the career guidance event. For this contingent of listeners, several workshops are held on one topic with a duration of 20 to 40 minutes. This time is enough for the lecturer to bring the basic information to the listeners and to ensure high-quality assimilation of this information by them. As a result, the lecturer gets tremendous experience, which in the future process of creative thinking will give him a new round in perfection and professional development.

Open Days are held to ensure a sustainable positive image of the branch. These days the branch is full of people interested in getting higher education at the branch. Applicants themselves, their parents, teachers of academic teaching staff, branch graduates and production workers attend this event [6,7]. The event is aimed at informing the population about the activities of the branch and USPTU, about the fields of training and specializations being implemented, about their priorities, opportunities and prospects, about the procedure of the admission campaign. Consultations are being held with applicants and their parents. The differences between full-time and part-time, budget and contractual forms of education, and the benefits of each of these forms are explained [8].

According to the standard indicators, the share of foreign citizens studying at the branch should increase substantially. For this purpose, the measures in the form of travel campaigns have been taken to attract citizens of the Republic of Kazakhstan to the cities of Uralsk and Atyrau. The work was carried out by teachers of the branch together with representatives of the USPTU in the framework of the career guidance plan of the USPTU. Meetings, presentations were held with schoolchildren to increase the attractiveness of the branch and USPTU, and also to conduct the questioning and preliminary testing to identify potential applicants.

\section{Conclusions}

Career guidance has a positive effect on the rating of the branch, on its image in the eyes of applicants, on sustainable public opinion and further development prospects.

The main activities of the Oilfield Machinery and Equipment department in this area: 1) expanding and strengthening ties with the production sector: 2) developing additional and continuing education: 3) increasing the graduate mobility in the labor market; 4) increased interaction with the companies of fuel and energy complex.

\section{References}

1. L. Pan, Research on paths to cultivate occupational quality of higher vocational college students under the guidance of the spirit of the craftsman, Proc. of the 2nd Int. Conf. on contemporary education, social sciences and humanities (ICCESSH 2017): Advances in social sci. ed. and humanities res, 124, pp. 205-208 (2017)

2. R.M. Shaidullina, A.F. Amirov, V.S. Muhametshin, K.T. Tyncherov, Designing Economic Socialization System in the Educational Process of Technological University, European J. of Contemporary Ed., 6(1), 149-158 (2017). DOI: 10.13187/ejced.2017.1.149

3. V. Motlova, P. Honsova, K. Viteckova, Use and adaptation of career adapt-abilities scale in Czech university students, Proc. of the 15th Int. Conf. efficiency and responsibility in education 2018 (ERIE): Efficiency and Responsibility in Ed., 229-234 (2018)

4. E.L. Guseinova, Organizational and pedagogical conditions for the development of professional competencies in the technical students' individual work through the example of studying the discipline "Hydraulics and fluid mechanics", Eur. J. of Contemporary Ed., 7(1), 118-126 (2018)

5. S. Lutovac, R. Kaasila, J. Komulainen, University lecturers' emotional responses to and coping with student feedback: a Finnish case study, Eur. J. of psychology of ed., 32(2), 235-250 (2017). DOI: $10.1007 / \mathrm{s} 10212-016-0301-1$

6. R.I. Suleimanov, L.Z. Zainagalina, M.Ya. Khabibullin, L.M. Zaripova, N.O. Kovalev, Studying heataffected zone deformations of electric arc welding. IOP Conf. Ser. Mater. Sci. and Engineer., 327(3) $032053 \quad$ (2018). DOI: $10.1088 / 1757-$ 899X/327/3/032053.

7. D. Zhang, Yu. Qin, Sh. Zhang, Analysis and Countermeasures of University Students' Employment Problem under New Situation, 6th Int. Conf. on Ed. and Sports Ed. (ESE 2016), Pt 1: Lecture Notes in Management Sci., 51, 169-173 (2016)

8. R.F. Yakupov, V.Sh. Mukhametshin, K.T. Tyncherov, Filtration model of oil coning in a bottom water- 
drive reservoir, Periodico Tche Quimica, 15(30), 725-733 (2018)

9. M.Ya. Khabibullin, R.I. Suleimanov, Selection of optimal design of a universal device for nonstationary pulse pumping of liquid in a reservoir pressure maintenance system, Chemical and Petroleum Engineering, 54(3-4), 225-232 (2018)

10. Huixin $\mathrm{Wu}$, Exploration of the Mode of the Employment Guidance for the College Students under the Training of the Vocational Cultivation, 4th Int. Conf. on Social Sciences and Society (ICSSS 2015), Pt 2: Advances in Ed. Res., 71, 266-271 (2015) 